\title{
TRACING TROUBLED TIMES: OBJECTS OF VALUE AND NARRATIVES OF LOSS FROM SUMBA AND TIMOR ISLANDS
}

\section{Jill Forshee}

\section{Introduction}

Since 1998 I have been seeking local histories of the cultural consequences of international collecting of objects of value from the islands of Sumba and Timor, in the eastern region of the Indonesian archipelago. ${ }^{1}$ My search of cases from the past century has encountered a kind of folklore of loss-of a variety of narratives telling of the disappearance of weavings, carvings, jewelry, and even gravestones. Following upon the Indonesian political and economic crises that began in 1997, such narratives also reveal that the loss of these valuables has continued, perhaps even accelerated, in the present period.

\footnotetext{
${ }^{1}$ My research for this project began in 1998, facilitated by the Faculty of Arts and the Centre for Southeast Asian Studies at Northern Territory University in Darwin, Australia. Between 1999 and 2001 the Australian Research Council funded my work through a Large Grant. I am most grateful for the research support in Australia, and I especially thank James Bennett for generously sharing his deep knowledge of Indonesian arts. I owe much to the many kind people I spoke with in Sumba, West Timor, and East Timor, whose stories form the basis of my work. This article grew out of an earlier paper presented at the Eighteenth Annual Conference on Southeast Asia Studies-"Mass Political Violence in Twentieth-Century Southeast Asia: Causes, Consequences, Representations" - at the University of California at Berkeley, February 16-17, 2001. This expanded version benefited from incisive comments from Herbert Phillips, Sandra Cate, Janet Hoskins, Kaja McGowan, Elizabeth Traube, and Craig Latrell. Certain portions of the text under the heading "A Grave Robbing in Sumba" are partial excerpts from my book, Between the Folds: Stories of Cloth, Lives, and Travels from Sumba (Honolulu: University of Hawaii Press, 2001).
} 
66 Jill Forshee

Objects of value from Sumba and Timor have moved along trade routes for centuries, traveling far from their places of origin. Rooted in local histories, beliefs, and personal displays, such possessions often have left stories in their absence, many tinged with resentments after secretive trade or theft. Worldwide demand for what I will shorthandedly (and not unproblematically) term "arts" 2 accelerated tremendously in the last decades of the twentieth century, following both a boom in international tourism in Indonesia and a flourishing global commerce in "ethnic arts"-drawing in goods from many non-Western societies into a largely Euro-American market.

Although my work has been mostly in Indonesian areas, in 2000 it expanded to East Timor. In the wake of rampant destruction of this region in 1999, following a popular referendum for independence from Indonesia, East Timor remains largely in ruins. After this referendum, violence swept all of Timor Island, producing many trajectories for East Timor arts, spilling across the island and beyond. In recent years of tumult, objects of this small nation have been burnt, stolen, or sold out of necessity, and many now join the art shop inventories of Indonesian urban centers.

This article offers a brief picture of the movement of objects through turbulent times and touches upon the historical nature of violence in the eastern Indonesian archipelago-often a compelling factor for international collectors seeking objects from the region. Based upon ethnographic research carried out between 1998 and 2001 and building upon earlier work, what follows is part of a larger project that investigates ethnographically the folklore about lost objects, in order to gain knowledge into local

\footnotetext{
2 I do not use the term "art" here in a strictly Western evaluative sense, underpinned by historical institutions (museums, university departments, art critics) and a certain public consensus. Rather, I consider "art" as taking on definition through a "system of action" (as discussed by Alfred Gell, Art and Agency: An Anthropological Concept [Oxford: Clarendon Press, 1998], p. 6) producing objects that carry a "particular type of social potential" (Arjun Appadurai, "Introduction: Commodities and the Politics of Value," in The Social Life of Things: Commodities in Cultural Perspective, ed. Arjun Appadurai [Cambridge: Cambridge University Press, 1986], p. 6). Such objects bear specific values and meanings in the social contexts of their creation and in fluctuating realities that follow and stimulate ongoing commentary among their owners. As Christopher Steiner recently noted, in movements through time and space, objects potentially shift categories and slide along slippery lines dividing art from artifact from commodity. See Christopher Steiner, "Rights of Passage: On the Liminal Identity of Art in the Border Zone," in The Empire of Things: Regimes of Value and Material Culture, ed. Fred R. Myers (Santa Fe, AZ: School of American Research, 2001), p. 224. Steiner's use of "bordercrossing" (a concept discussed by many in recent literature) both conceptually and geographically resonates with my study of the movements of Indonesian and, perhaps most saliently, East Timor arts. Indeed, such arts take on a sort of "border fetishism," (Patricia Spyer, ed., Border Fetishisms: Material Objects in Unstable Spaces [New York and London: Routledge, 1998]), oscillating between domains geographical, political, and ideological. Moreover, as Margaret Wiener discusses in her work on Bali, objects (both natural and manufactured) can be crucial intersections between visible and invisible realities. Margaret Weiner, Visible and Invisible Realms: Power, Magic, and Colonial Conquest in Bali (Chicago and London: The University of Chicago Press, 1995), p. 55. I believe that in the absence of lost objects, visible and invisible realities can be bridged by explanatory stories. Also see discussions on art and anthropology by James Clifford, The Predicament of Culture: Twentieth-Century Ethnography, Literature, and Art (Cambridge Mass. and London: Harvard University Press, 1988); by Nelson Graburn, ed., Ethnic and Tourists Arts: Cultural Expressions from the Fourth World (Berkeley: University of California Press, 1976); by Shelly Errington, The Death of Authentic Primitive Art and Other Tales of Progress (Berkeley, Los Angeles, and London: University of California Press, 1998); and by George E. Marcus and Fred R. Myers et al., eds., The Traffic in Culture: Refiguring Art and Anthropology (Berkeley, Los Angeles, and London: University of California Press, 1995).
} 
life, memory, and comparative social-cultural outlooks through profoundly troubled times.

This folklore might also trace processes of "disenchantment" 3 brought about through modern Indonesian pressures such as education, religious conversion, new technologies, but especially involving state citizenship and military force. Local stories thus might "re-enchant" sites of loss, at least partially reconcile people to how and why things got away, and recapture some sort of ownership. When people lament their disempowerment through stories of the loss of their sacred objects and as they attempt to reclaim moral authority related to such loss, they demonstrate that "narratives are not only structures of meaning, but structures of power as well." 4

Stories in this account reveal a kind of "social life of things"5 told of movement, loss, reconciliation, and sometimes recovery. ${ }^{6}$ Moreover, politics of international collecting eventually affect local politics of ownership and identity. As Nicholas Thomas has noted, "The circulation of objects, especially across the edges of societies, civilizations, and trading regimes, is not merely a physical process but is also a movement and displacement of competing conceptions of things, a jostle of transactional forms." ${ }^{\prime 7}$ In such conceptions and jostling of objects, explanatory tales inevitably arise, as the movement of their objects to regions across local boundaries especially challenges people's imaginations, marking the events of their displacement in

${ }^{3}$ Cf. Max Weber, "Science as a Vocation," in From Max Weber: Essays in Sociology, ed. H. H. Gerth and C. Wright Mills (New York: Oxford University Press, 1958), pp. 129-156.

4 Edward M. Bruner, "Ethnography as Narrative," in The Anthropology of Experience, ed. Victor W. Turner and Edward M. Bruner (Cambridge, MA and London: Harvard University Press, 1986), p. 144. I examine narratives here as means of personal or cultural reconstruction in the wake of often devastating loss. That is, they are "redressive" in their moral implications. See Victor Turner, The Anthropology of Performance (New York: PAJ Publications, 1986), pp. 38-39. As structures that organize and give meaning to experience (Bruner, "Ethnography as Narrative," p. 143), narratives also have possibilities in themselves to fashion gaps in the order of things (Kathleen Stewart, A Space on the Side of the Road: Cultural Poetics in an "Other" America [Princeton: Princeton University Press, 1996], p. 3). Such fashioning involves strategy and imaginative play. Moreover, narratives are performative, relying upon an audience and positioning the teller and others socially. See Richard Bauman, Story, Performance, and Event: Contextual Studies in Oral Narrative (Cambridge: Cambridge University Press, 1986). Historically in eastern Indonesia, such performance often takes form through ritualized speech. Studies of such speech include James J. Fox et al., eds., To Speak in Pairs: Essays on the Ritual Languages of Eastern Indonesia (Cambridge: Cambridge University Press, 1988); Janet Hoskins, The Play of Time: Kodi Perspectives on Calendars, History, and Exchange (Berkeley, Los Angeles, and London: University of California Press, 1993); Webb Keane, Signs of Recognition: Powers and Hazards of Representation in an Indonesian Society (Berkeley, Los Angeles, and London: University of California Press, 1997); Joel Kuipers, Power in Performance: The Creation of Textual Authority in Weyewa Ritual Speech (Philadelphia: University of Pennsylvania Press, 1990) and Elizabeth Traube, Cosmology and Social Life: Ritual Exchange among the Mambai of East Timor (Chicago and London: University of Chicago Press, 1986). In this article, I write of stories told to me in non-ritualized language, in more or less "everyday speech" that I largely heard and translated from Bahasa Indonesia, in mixture with local languages. In East Timor I was able to use and understand a limited amount of Tetum language and in East Sumba I understand and used the language of Kambera.

5 A. Appadurai, ed., The Social Life of Things: Commodities in Cultural Perspective.

${ }^{6}$ For some recent frames for "things on the move," see F. Myers, ed., The Empire of Things: Regimes of Value and Material Culture, and P. Spyer, ed., Border Fetishisms: Material Objects in Unstable Spaces.

${ }^{7}$ Nicholas Thomas, Entangled Objects: Exchange, Material Culture, and Colonialism in the Pacific (Cambridge, Mass. and London: Harvard University Press, 1991), p. 123. 
memory. Such narratives might form resolutions of sorts, woven strains of stories constructing moral outcomes that serve those who tell them. ${ }^{8}$ I will illustrate something of this here.

In Biographical Objects: How Things Tell the Stories of People's Lives, Janet Hoskins writes of society in the Kodi region of West Sumba as where "still deeply focused on ancestors as well as rapid social change, biographical objects provide a point of orientation and an 'anchor' for storytelling that is really a form of autobiography, a reflection on the self deflected through the medium of the object." ${ }^{\prime \prime}$ Hoskins illustrates how objects are given significance in human stories, by the way they become narratives of self-presentation. ${ }^{10}$ Such narratives, in Sumba and Timor, are entwined with issues of identity and status and accentuated by the rapidity of both social change and shifting forms of authority in each region.

Arts long have asserted power and prestige in eastern Indonesia, as intricately carved doors, sculpted grave markers, or complex fabrics marked the domains of nobility. Such objects denoted status in societies often divided historically into rigid systems of hierarchy, with regional groups in frequent warfare with one another. Thus acts of headhunting, sacrifice at ritual events, and severe physical punishments were realities of social life in this Indonesian region, continuing in some places in recent times. Indeed, much of the violence sweeping Indonesia and East Timor in recent years echoes ritualistic practices of the past, such as war raids and headhunting, often building upon historical animosities. ${ }^{11}$

Contemporaneous conditions of violence are rarely described in literature on the arts of Indonesia. In places across the archipelago (such as Ambon, Aceh, West Papua, and recently East Timor), these conditions currently reveal something like what Michael Taussig characterizes as a "chronic state of emergency."12 Sally Price criticizes Western commentators on non-Western arts in general for "choosing to focus attention on the role of beauty and harmony in human relations" and thereby ignoring how "like many kinds of ideological currency ... this is a coin with two sides."13 Until quite recently anthropologists tended to cast social inequality or conflict in eastern Indonesia

\footnotetext{
${ }^{8}$ See Paul Ricouer, Time and Narrative, vol. 1 (Chicago: University of Chicago Press, 1984) see also Hayden White, "The Value of Narrativity in the Representation of Reality," Critical Inquiry 7,5 (1981).

9 Janet Hoskins, Biographical Objects: How Things Tell the Stories of People's Lives (New York and London: Routledge, 1998), p. 112.

10 Ibid., p. 185.

11 See David Mitchell, "Tragedy in Sumba: Why Neighbors Hacked Each Other to Death in a Remote Part of Indonesia," Inside Indonesia 58 (1998): 8-20. See also Jacqueline Vel, "Tribal Battle in a Remote Island: Crisis and Violence in Sumba (Eastern Indonesia)," Indonesia 72 (2001): 141-58.

12 Michael Taussig, The Nervous System (New York and London: Routledge, 1992). Taussig builds on ideas of Walter Benjamin, "Theses on the Philosophy of History," in Illuminations, ed. Hannah Arendt, trans. Harry Zohn (New York: Schoken, 1969), pp. 253-64. Indeed, the violence experienced by people I have spoken with in East Timor engenders an emotional outlook that compares to "magical realism"-a folkloristic phenomenon of making sense of the world in the wake of atrocities (and particularly characterizing certain novels from Central and South America). See Nancy Scheper-Hughes, Death without Weeping: The Violence of Everyday Life in Brazil (Berkeley, Los Angeles, and London: University of California Press, 1993); see also Taussig, The Nervous System.

13 Sally Price, Primitive Art in Civilized Places (Chicago and London: The University of Chicago Press, 1989), p. 5.
} 
as "social structure" or "the way power works." Messy issues of violence, in the "ethnographic present"14 of much anthropological analysis of the region, often appear in the past tense-or as realms of symbolism or mythology-and not in terms of present lived conditions.

Nonetheless, images of "violent" societies perpetuate a peculiar type of international value attached to arts, from image-charged places like Oceania or Africa, or from historical headhunting societies in Sumba and Timor. What Price calls the "Night Side of Man"15 often dominates descriptions of non-Western arts globally. Hoskins notes that the European lore regarding headhunting over the past century has bestowed upon the headhunter a place alongside the cannibal and the noble savage in constituting an image of the exotic for Western audiences. ${ }^{16}$ This imaging of the exotic fuels a far-flung market for arts of Indonesia, indeed, one that responds to recent conditions of upheaval in the archipelago.

Stories I have collected describe the theft of gold items, textiles, and gravestones from Sumba ${ }^{17}$ (at times involving murders of local people); the disappearance of most of the dramatically carved wooden doors that once distinguished ceremonial houses of West Timor; ${ }^{18}$ the movement of sacred figures from East Timor through wartime conditions; ${ }^{19}$ and the eventual resurfacing of some such objects in foreign collections and museums. ${ }^{20}$ Here, however, I will relate two stories taking different turns: one involving lost grave treasures from Sumba and the other a "recovered" wooden angel from a ceremonial house in East Timor.

${ }^{14} \mathrm{Cf}$. Johannes Fabian, Time and the Other: How Anthropology Makes Its Subject (New York: Columbia University Press, 1983).

15 Price, Primitive Art in Civilized Places, p. 55.

16 Janet Hoskins, "Introduction: Headhunting as Practice and Trope," in Headhunting and the Social Imagination in Southeast Asia, ed. Janet Hoskins (Stanford, Cal: Stanford University Press, 1996), p. 1.

17 See Marie Jeanne Adams, System and Meaning in East Sumba Textile Design: A Study in Traditional Indonesian Art (New Haven, Conn.: Southeast Asian Studies, Yale University, 1969); Hoskins, Biographical Objects; and Forshee, Between the Folds, for illustrations and discussions of such objects of value.

${ }^{18}$ See B. Vroklage, Ethnographie der Belu in Zentral Timor, 3 volumes (Leiden: Brill, 1952-53) for illustrations and discussion of these.

${ }^{19}$ For illustrations of such figures, see Ruy Cinatti, Motivos Artísticos Timorenses e a Sua Integração (Lisbon: Museu de Ethnologia, 1987), pp. 88-89. See E. Traube, Cosmology and Social Life: Ritual Exchange among the Mambai of East Timor, for ethnographic description of life in the Aileu region of East Timor in the pre-Indonesian 1970s. See also Shepard Forman, "Descent, Alliance, and Exchange Ideology among the Makassae," in The Flow of Life: Essays on Eastern Indonesia, ed. James J. Fox (Cambridge, Mass. and London: Harvard University Press, 1980), pp. 152-77. In the same volume, see Brigitte Clamagirand, "The Social Organization of the Ema of Timor," pp. 134-51. Also refer to Brigitte Renard Clamagirand, Une Societe Ema de Timor, Langues et Civilizations de L'Asie du Sud-Est du Monde Insulindien No. 12 (Paris: SELAF/CNRS, 1982).

${ }^{20} \mathrm{It}$ is not my intention to "expose" in this account any museum or private collector for obtaining objects stolen from their sources. For years I have collected Indonesian arts (both for myself and for museums), and I also have curated museum exhibitions and contributed to a catalogue about arts of Sumba. I claim no special exemption from the risks of buying articles of uncertain provenance. While there is certainly a long history of unscrupulous means of acquisition of Indonesian valuables by international buyers, I nevertheless suspect that many collectors who buy objects obtained illegitimately from their sources may do so unwittingly. 
$70 \quad$ lill Forshee

\section{A Grave Robbing in Sumba}

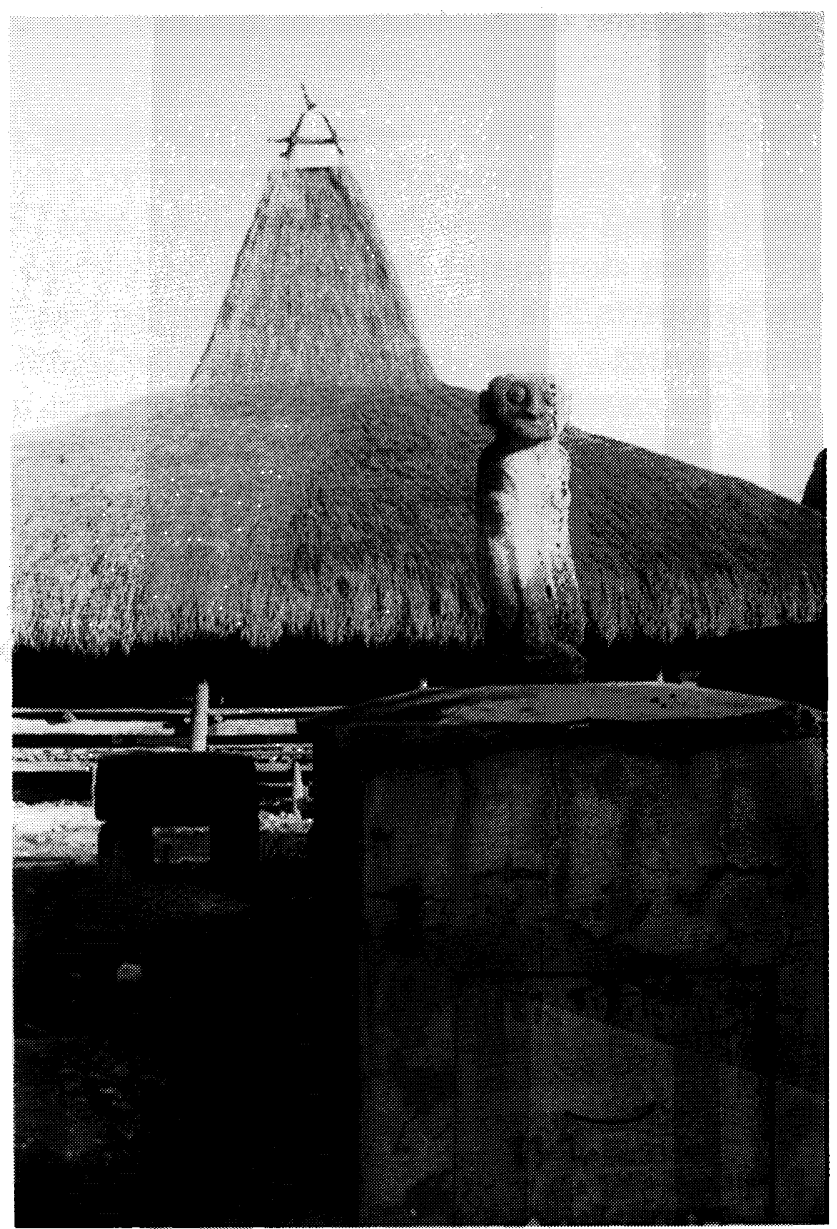

Graves in an East Sumba village. Photograph by Jill Forshee, 2001.

Many in eastern Sumba recount tales of a grave robbing that took place in the 1970 s. Set in a region largely given to animist practices, Sumba's graves are central in social life and cosmology. In their size and elaboration, graves also mark social status of people and clans, and contain articles of wealth. ${ }^{21}$ According to various versions of this story, in the middle of the night a number of men descended from a truck, lifted the stone slab from the top of a grave, and after grabbing bundles containing gold treasures, also took the carved stone grave marker. From their homes, people heard the invasion and some came out to defend their gravesite. Resulting gunfire killed four villagers, and the truck sped off with the plunder.

Several years later, following accounts in Sumba, the stone marker and several gold items from the grave appeared in the glossy pages of a publication from a European museum. Some in eastern Sumba received copies of this book through their connections

21 See Adams, System and Meaning in East Sumba Textile Design; Gregory Forth, Rindi: An Ethnographic Study of a Traditional Domain in Eastern Sumba (The Hague: Martinus Nijhoff, 1981); and Forshee, Between the Folds, for examples of beliefs around death and graves in eastern Sumba. 
with tourists. ${ }^{22}$ In the acknowledgment section of this exhibition catalogue, the author/curator thanked by name a trader from another Indonesian island who had lived for years in Sumba. Many in East Sumba considered this trader to be a criminal and some said that he long had worked in league with the police and military in coercing villagers to sell their objects, or even in stealing such goods. What is more, local people believed that a government official (also from another island, but residing in Sumba) had directed the grave robbery of the 1970s. Moreover, this man was despised for demanding monetary kickbacks from numerous textile vendors selling to tourists in East Sumba. Over time, stories spread through the region of the grave robbing and the suspected culprits, and folklore emerged about the objects that got away.

Over a decade after the theft and murders, the suspected official's local standing was forever altered through an unforeseeable event that created new "discursive" conditions in East Sumba. The official happened to pass a hotel one morning, where a drunken textile vendor had passed out near the entranceway the night before. Proprietors of the hotel were becoming nervous, as attempts to resuscitate the vendor had failed and a crowd was gathering around him. The official-long detested by the local vendors-stepped into the scene and began giving orders to the five textile sellers present, commanding them to move their comrade from the hotel entrance to the driveway, where he could be taken away. The vendors responded sluggishly to the orders, and the official grew impatient. The unconscious villager was a slight man, yet seemed inexplicably heavy for the five who labored to move him from the walkway. His body sagged to the ground as the other vendors attempted to drag him by his wrists and ankles. The increasingly agitated official barked his order for the men to lift the inebriate from beneath his body, and he grew enraged as the noncompliant vendors adopted attitudes of dumb confusion. Perhaps thirty people had gathered around the scene at this stage, including local passersby, the hotel staff, and foreign guests, including myself.

Finally losing all patience, the official bolted into the midst of the group, thrust his hands under the limp man's rump as the others still held his limbs, and with a shout and a jerk elevated the man from the walkway. No sooner had the passively resistant vendor gone up when he rapidly came down, with the shocked official holding out his hands in horror and shrieking for a basin of water and a towel. Some of the bystanders stifled their laughter, others looked away or dispersed in embarrassment, while a few children squealed and several foreign tourists laughed openly.

This event became a relished tale in the eastern Sumba region and thus entered local lore. In the following weeks, many village verandahs rang with the laughter of people listening to a rendition of the story, which generally came to be called "hinggi tai" ("feces cloth" in the local Kambera language). Textile vendors who had been at the scene of the tale enjoyed a newfound popularity as orators, holding audience with groups of rapt villagers. One man repeatedly offered a moral at the end of his tale: "For years [the official's] hands were soiled from stealing our profits from cloth. Now let them be soiled from our cloth!" Through his humble loincloth, an elderly inebriate

22 Elsewhere (Forshee, Between the Folds) I describe an evolution of relationships between people in eastern Sumba and international tourists and collectors involving the trade of local textiles. By the mid1980s, many in Sumba were sophisticated in their knowledge and strategies regarding a global arts market. 
had unwittingly left an indelible social imprint on a local power elite, compromising the latter's prestige as he lost face publicly. Such was the public ridicule and humiliation following this event that the official left Sumba and returned to his home island. ${ }^{23}$ The feces cloth story further embellished the grave robbing folklore, as the doubly culpable official's demise had been facilitated through a hand-woven cloth produced in the region of the crime years before.

In this way, a certain reconciliation took place in Sumba, through an object "enacting" justice for its creators and bringing accounts full circle.

\section{An Angel from East Timor}

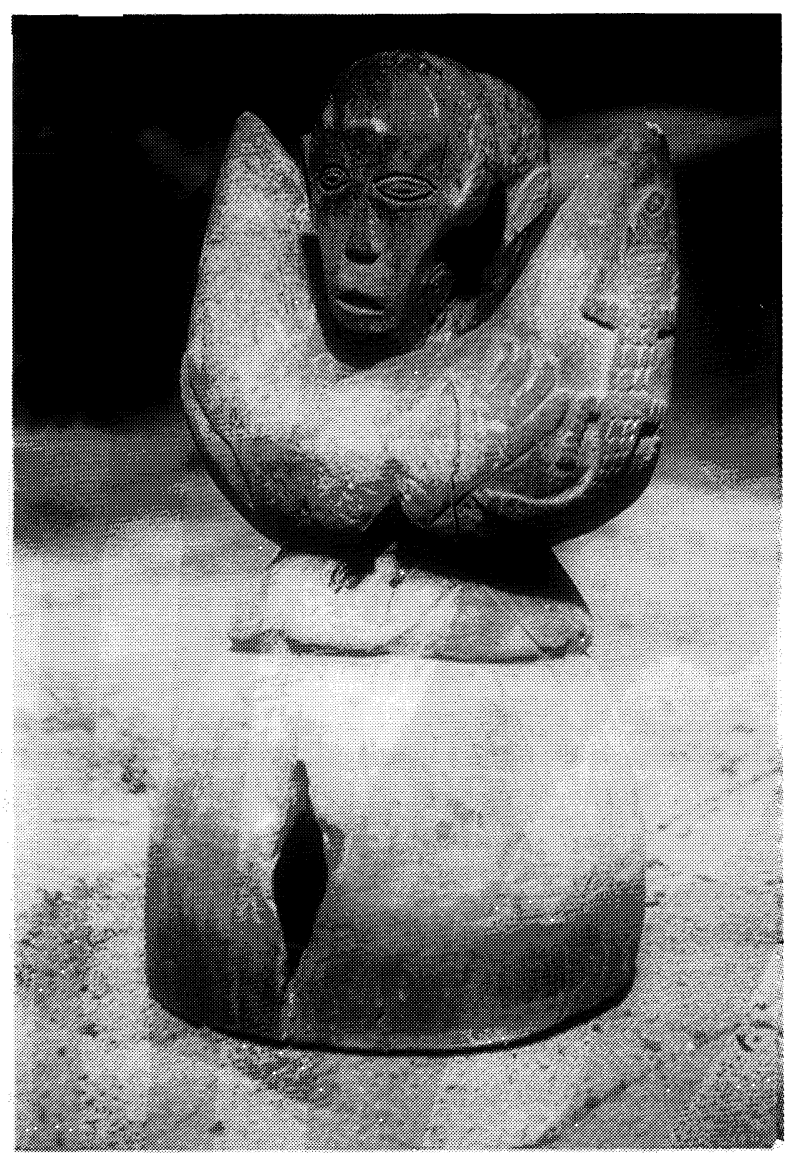

A wooden angel from East Timor. Photograph by Jill Forshee, 2001.

In May of 1999, I visited the small house of an itinerant trader in the Indonesian city of Kupang, West Timor. A corner of the two-room hut contained perhaps fifty wooden objects from around the island. Unique amidst the pile of decoratively carved doors and stark ancestral figures, a wooden angel caught my eye. Shaped like a bell, with upturned wings carved with crocodile motifs, the angel's two enigmatic faces

23 See Forshee, Between the Folds, pp. 145-47, for an earlier description of this event and its aftermath. 
peered downward atop either side of its body. The carving was sixteen inches high, twelve inches across at the base, weighed about fifteen pounds, and resembled a finial for the rooftop of a conical Timor house. The Kupang merchant told me that he had recently bought the carving from a certain trader in Balibo, a border town in East Timor. ${ }^{24} \mathrm{He}$ was able to offer no other information, and I bought the angel with some trepidation.

I had witnessed over the past months an increasing flow of collectible objects from East Timor (often distinctive with Catholic iconography) to Indonesian market centers like Kupang, Denpasar, and Jakarta. ${ }^{25} \mathrm{I}$ imagined that this commerce was laced with tragedy, finding an outlet in an international demand for what were in truth spoils of war. Underscoring this market was an ongoing state of mass violence that continuously produced charred or partially destroyed objects that enlivened the sales pitches of traders of arts. Burn marks or machete hackings characterizing carvings said to originate from East Timor attested to their authenticity in the arts boutiques catering to tourists in Bali, hundreds of miles to the west of Timor Island.

I returned to Darwin, Australia, with the wooden angel, where it took on a mysterious presence in my home. Curators at the Museum and Galleries of the Northern Territory, familiar with Timor arts, had seen nothing like this piece before, but they estimated it to be about eighty years old. I was able to find nothing resembling the angel in any literature about Timor.

The following year, in August of 2000, I carried photographs of the carving to East Timor to try to trace its origins. I toured much of the country, showing the photos and questioning people. One old man from the western border region of Loes had seen such figures in the past and had heard that most such carvings (generally termed "lulik" 26 in

\footnotetext{
24 This is also a region with a vivid history of military violence relating to the struggle between eastern Timorese advocates for national independence and an imposed Indonesian state authority, beginning with the invasion of the former Portuguese colony in 1975. Among the extensive literature about this struggle, see Desmond Hall and Hamish McDonald, Death in Balibo, Lies in Canberra (St. Leonard's: Allen \& Unwin, 2000); Carmel Budiardjo and Liem Soei Liong, The War Against East Timor (London: Zed Books, 1984); Peter Carey and G. Carter Bentley, East Timor at the Crossroads: The Forging of a Nation (New York: Social Science Research Council, 1996); Xanana Gusmão, To Resist is to Win: The Autobiography of Xanana Gusmão, ed. Sarah Niner (Victoria: Aurora Books, in association with David Lovell Publishing, 2000); Jill Jolliffe, East Timor: Nationalism and Colonialism (St. Lucia: University of Queensland Press, 1978); John Taylor, East Timor: The Price of Freedom (London and New York: Zed Books, 1999); and Richard Tanter, Mark Selden, and Stephen R. Shalom et al., eds., Bitter Flowers, Sweet Flowers: East Timor, Indonesia, and the World Community (Lanham, Maryland: Rowman \& Littlefield Publishers, 2001).

25 See Eric Crystal's critical account of the effects of the international market for sacred figures from Toraja, Sulawesi, in E. Crystal, "Rape of the Ancestors: Discovery, Display, and Destruction of the Ancestral Statuary of Tana Toraja," in Fragile Traditions: Indonesian Art in Jeopardy, ed. Paul Taylor (Honolulu: University of Hawaii Press, 1994), pp. 29-41. Also see Kaja McGowan's rich and fascinating discussion of a unique sort of collection and transformation of objects resulting from Indonesian military presence in East Timor. Kaja McGowan, "Chasing Sita on a Global/Local Interface: Where Cartographies Collide, Silent Vessels 'Tell in Full,"' in The Ramayana Revisited: Gender, Performance, Iconography, and Narrative Design, ed. Mandakranta Bose (Oxford and New York: Oxford University Press, Forthcoming).

26 A reverence for $l u l i k$ objects and their equally sacred sites is still strong throughout East Timor. Aside from many village people, Timorese Catholic nuns and priests I spoke with all seemed to acknowledge the power of such objects, and one nun commented to me that they carried an especially potent "karisma" ("charisma," Ind.). Indeed, Xanana Gusmão, famed leader of East Timor's decades-long battle for independence from Indonesia and recently elected president of the new nation, tells of the persistent
} 
the local Tetum language, which means "sacred") had perished in the mass incineration of the year before.

In November of 2000, following a tip about the source of the angel, I hired a man in the city of Dili to drive me to the war-devastated area of Maliana, near the border with Indonesian West Timor. As we rode the length of the long, green Maliana valley, I wondered what survivals could have been possible here-whether people or objectsfrom a horrific repetition of bombed, burned, gutted, and roofless former homes and public buildings. As we traveled on, I recalled a passage I had read the day before in a United Nations publication about East Timor. Brennon Jones had described " . . a kind of devastation so thorough, so vengeful ..." where incinerated buildings of the most humble sort cried out, "Look! Even to me in this quiet, lovely place, it has happened!"27 This last exclamation haunted my stay.

My driver took me to the house of a man known for his knowledge of regional history. While still reconstructing his razed home, this man already had rebuilt a sacred house (uma lulik) beside it. Immediately claiming to recognize the images in my photographs, the historian drove me to an outlying village the following day.

Led by two elderly men, we began a grueling four-hour climb to a mountaintop. At the summit, we entered a forest and followed an overgrown trail for another kilometer.

Everyone suddenly halted, and I was beckoned to sit on a low rock. All fell silent as I realized I was within an ancient sacred house site the Maliana historian had told me about the day before. Eight wooden house posts encircled the forest setting in various stages of tropical decay. Before me loomed a mossy pillar carved with interlocking, swirling patterns. The angel of my photographs, one elder said, had once sat atop this post as a guardian of the house. I could not help but muse that I was experiencing something reminiscent of a scene from an "Indiana Jones" film-a cinematic cliché of heroic anthropology.

At the uma lulik site, we were not meant to speak much, but after descending to the village, older people began to relate what they knew of the angel's disappearance. Decades ago, a disaffected clan member stole the figure and took it across the border to the Belu area of West Timor. After some years, someone brought the angel back to East Timor, to a village north of Maliana with clan relations to the original owner, who had died during the carving's absence.

The returning angel had arrived at a village that eventually was burnt entirely to the ground in 1999, people said, by the Indonesian-backed militia opposing the independence of East Timor. This destruction included the village sacred house, which

importance of luliks in the cultural heritage of East Timor, and of how he personally drew strength from mountain lulik sites during his years as a guerilla fighter. See Gusmão, To Resist is to Win. From an environmental standpoint, Andrew McWilliam recently argues that " . . the prospect for developing successful conservation forestry in both East and West Timor may well be found in the existence of sacred forests and groves across the Timorese landscape." Andrew McWilliam, "Prospects for the Sacred Grove: Valuing Lulic Forests on Timor," The Asia Pacific Journal of Anthropology 2,2 (2001): 89-113. Elizabeth Traube refers to "luli" (from the Mambai region east of the area I visited, discussed here), and discusses the double meaning of this term as "sacred" and "prohibited." Traube, Cosmology and Social Life, pp. 142-43.

27 Brennon Jones, in Timor Loro Sa'e: Tinan Importante Ida-One Momentous Year (Dili, East Timor: United Nations Transitional Administration in East Timor, Publications Unit), p. 74. 
had sheltered three lulik figures. If this was so, then the angel in my possession had escaped incineration a few months before the catastrophe, through its sale to the trader on the border.

After recently piecing together stories told in the region of the razed village, I came to suspect that someone stole the wooden angel from the sacred house, then sold it to the Balibo trader who subsequently expedited its movement to Kupang. The story blurs here, as neither the village nor the trader remain in East Timor. Villagers who survived the scorched earth methods of the pro-Indonesian militia were yet scattered about the mountain area in East Timor or in refugee camps on the Indonesian side of the border, as of my last visit in August of 2001. I hope to uncover further stories of the angel and the lives of people of this region through upcoming fieldwork, and I will return the carving to its village of origin. ${ }^{28}$

What has surfaced thus far, however, suggests a kind of re-enchantment in the region where the lulik figure (from all reports) originally sat. At the top of the mountain near Maliana, old men spoke in whispers of how they had fled to the site to hide during the years of intimidation by the Indonesian military. In 1999, the population of the entire village region had climbed to safety at the forest spirit site, thus escaping the murderous rampage being carried out below by the militia. These elders claimed that the secrecy and power of the mountaintop uma lulik protected all who went there. They marveled at how the angel had finally found its way back, if only in photographic form, 29 and they seemed to regard it as miraculous that I could communicate with them in mixed Indonesian and Tetum languages, however awkwardly.

"Why do you want to bring the lulik back to us?" they asked, puzzled.

"I thought it might have been stolen," I answered, knowing that I had not satisfied their question and that I also appeared naive to them.

"Yes, yes, this is a very good thing," said one man, "Since the loss of this lulik our village has not prospered. This is luck (untung, Ind.), but we must build another spirit house before we can receive it again properly."

\footnotetext{
${ }^{28}$ Skeptics might question whether this object is indeed from the community I describe, and I have no independent proof that it is. My account here is based on conversations with people, reactions from them to my photographs of the object, and the number of people who came out to tell stories of their own connections to the angel or to substantiate those of others. I will learn more through ongoing research. Of course, I cannot predict what will become of the figure after I return it. Nor can I foresee interpretations, power contests, or further movements of the angel that will follow. Gregory Forth provides a thought-provoking account of how "an ethnographer armed with a photograph" (p. 161) affected local interpretations of a statue in Flores, in "How a Wooden Horse Became a Flying Naga: Recovery or Invention of Tradition among the Nage of Eastern Indonesia," in Structuralism's Transformations: Order and Revision in Indonesian and Malaysian Societies, Papers Written in Honor of Clark E. Cunningham, ed. Lorraine V. Aragon and Susan D. Russell (Tempe, Ariz.: Arizona State University Program for Southeast Asian Studies, 2000), pp. 141-68.

${ }^{29}$ I left copies of the photograph of the angel with village elders and with the historian who had taken me to the village. The night that he received the photo from me, the latter left the picture in his locked truck. The following morning the photograph was gone, the truck bore no signs of having been broken into, and the visibly shaken historian surmised that the photograph had indeed possessed the lulik spirit, which wanted to return to the mountaintop and thus had disappeared from his vehicle on its own.
} 
76 jill Forshee

After we descended to the village, about fifty people were waiting for us and some excavated and showed me a tall, carved lulik post that they had buried in the ground, wrapped in a blue plastic tarp for safe-keeping in the event of another attack. This post, one man explained, had long ensured sufficient rainfall and fertility of crops for the village. A new, large sacred house stood in the center of the rebuilding village-the first structure to have risen since the destruction of 1999. Constructed in the historical ovoid shape, its supporting pillars stood newly carved with interlocking motifs reminiscent of those decaying on the mountaintop. Its grassy roof poised intact, meticulously formed in timber framing with thatch neatly trimmed around the edges.

\section{Conclusion}

The movement and trade of arts from eastern Indonesia reflect the tumult of recent years, in both provenance and destinations and also in local explanations. New commercial routes and relations circumvent what was once a sovereignty in control of objects of value and markers of authority in Sumba, West Timor, and East Timor. Moreover, the stories of treasured objects from specific communities might "emplot" and trace something of the processes of local disenchantment brought about by Indonesian state forces of modernity. I suggest, nonetheless, that a kind of reenchantment emerges in the persistence of objects in people's memories and in the everevolving folklore circulating following the loss of things treasured. Such lore might become urgent as a device for social healing, responding to times of political violence, atrocities, and many forms of displacement.

An Indonesian modernity-through its intrusions, its violence, but also in its enticements-set in motion processes of disenchantment throughout the archipelago. Across the region of my study, this included a military presence that instilled a sense of state incorporation in some areas, but was nonetheless an intimidating force whose members sometimes demanded money or stole objects of value from local people. In East Timor, this presence was particularly heavy-handed. Inclusion within an Indonesian nation-state promoted modern systems of education, technology, and religious conversion throughout Sumba and West Timor through the 1950s and 60s (continuing in the present). Despite centuries of Portuguese colonial rule, however, most people in East Timor had neither become literate nor displaced from conventions and beliefs surrounding local life at the time of the 1975 Indonesian military invasion. Indeed, James Fox recently wrote of how remarkable it was that the kingdoms of this region identified by the Magellan voyage in 1522 persisted through the entire Portuguese colonial period of more than four hundred years. ${ }^{31}$ Thus, much of East Timor's encounter with a national Indonesian manner of modernity was relatively forced, swift, and traumatic.

In response to various types of violence, people shape explanations through stories that take on lives of their own. The tale of a murderous Sumba grave robbing, of people

30 Paul Ricouer, Time and Narrative, vol. 1.

31 James J. Fox, "Tracing the Path, Recounting the Past: Historical Perspectives on Timor," in Out of the Ashes: Destruction and Reconstruction in East Timor, ed. James Fox and Dionisio Babo Soares (Adelaide: Crawford House Publishing, 2000), p. 18. 
eventually viewing their stolen objects in a European catalogue, and of an unforeseeable event involving the personal humiliation of a suspected culprit (and despised government authority) provided people with a moral tale to at least partially resolve their losses. As Hoskins notes of the nature of narratives of objects, "The story is not finished until the counterpart is present." 32 In this grave-robbing case, the counterpart takes shape in a moral conclusion that reconciles the polarities of loss.

The far-flung arts of East Timor map out an especially troubled trade, as the homes and ceremonial structures once containing such objects for the most part no longer exist. Carvings, textiles, jewelry, and other arts have moved helter-skelter through a confusion of nationalist and independence struggles, revolution, holocaust, regional relations, and transnational politics and trade. Various "regimes of value"33 might contain such arts. What I discuss here is less about extant regimes than about events that initiate the unanticipated flow of objects, stimulating local explanations that become stories that illuminate something of objects, lives, and times.

Such stories might map out sites of ownership of objects and sometimes routes of their departure. In many cases, however, people have no idea of how their treasures disappeared in the night or the direction they followed. Yet, former owners nonetheless attempt to reconcile their losses in morally meaningful ways. ${ }^{34}$ One such tale of mystery involved a carved wooden door stolen from a ceremonial house in the Belu region of West Timor. Its owners claimed that no one had ever been able to sleep well in the vicinity of this door, because a nightmare involving a dagger-wielding woman always plagued those who had tried. This same fate befell anyone who viewed the door with thoughts of wrongdoing to its owners. One person remarked, "I heard that our stolen door went by a boat with many others to a museum in Paris. So be it. The new owners will never sleep well again."

\footnotetext{
32 Hoskins, Biographical Objects, p. 185.

33 See A. Appadurai, "Introduction: Commodities and the Politics of Value," pp. 4, 15, 30, 57; see also F. Myers, ed., The Empire of Things.

34 Another example of such moral reconciliation follows Hoskins's account of a story told in West Sumba of an heirloom sword pawned to a local raja to pay a gambling debt, and the lament over this loss of an object and its power by the family of the former owner. See Hoskins, The Play of Time, p. 57. Eventually in the possession of a Sumbanese living in Jakarta, the sword was stolen by burglars in 1999. Original owners of the sword in Sumba were convinced that the theft occurred because the sword was moved illegitimately off of the island. Hoskins, personal communication, March 2002.
} 
